\title{
ALAT PENGERING INTIP NASI YANG EFISIEN
}

\author{
Taufiq Hidayat ${ }^{1)}$, Sutrisno $^{2)}$ \\ ${ }^{1}$ Teknik Mesin, Universitas Nahdlatul Ulama Surakarta \\ Email: viqdmangan@yahoo.co.id \\ ${ }^{2}$ Teknik Mesin, Universitas Nahdlatul ulama Surakarta \\ Email: Trisnowmech_79@yahoo.co.id
}

\begin{abstract}
Abstrak. Salah satu makanan atau camilan ringan yang mudah ditemukan di masyarakat adalah intip yang berasal dari nasi. Tingkat ketergantungan terhadap panas matahari saat proses pengeringan sangat tinggi. Persoalan pengeringan terjadi manakala memasuki musim penghujan. Kesulitan proses pengeringan intip menyebabkan proses produksi intip mengalami penurunan bahkan bisa menyebabkan vakum produksi. Tujuan dari pembuatan alat pengering intip nasi adalah untuk membantu para UKM yang bergerak di pengolahan intip nasi baik yang intip nasi asli maupun buatan saat proses pengeringan. Saat memasuki musim penghujan untuk mempertahankan kapasitas produksi 75-100 bungkus intip per hari mengalami kesulitan. Kapasitas produksi pada musim penghujan hanya mampu mencapai $30 \%$ dari saat produksi normal.. Metode yang diterapkembangkan adalah survey ke UKM mitra, mendesain alat, pelaksanaan diskusi dengan mitra hubungannya dengan hasil desain, proses pembuatan alat, uji kinerja komponen, uji kerja alat danproses produksi. Hasil dari pelaksanaan program adalah sebuah alat pengering. Specifikasi: ukuran alat $90 \times 50 \times 170 \mathrm{~mm}$, jumlah rak 4, sumber panas falexibel (heat exchanger/arang/LPG), suhu ruang pengering mampumencapai $120^{\circ} \mathrm{C}$ dalam waktu 50 menit, satu rak mampu menampung \pm 1 kg intip, sumber udara tekan berasal dari blower. Kesimpulan dari pelaksanaan program adalah UKM mampu mempertahankan kapasitas produksi per harinya sebanyak 75-100 bungkus intip nasi buatan. Jumlah intip yang di keringkan bisa ditingkatkan dengan penambahan rak di ruang pengering.
\end{abstract}

Kata kunci: Intip Nasi, pengering, sirkulasi, rak.

\section{PENDAHULUAN}

Intip/kerak adalah lapisan nasi kering dan agak keras, dan sedikit hangus terbakar yang terdapat di dasar bagian dalam panci atau kuali penanak nasi. Kerak nasi tercipta akibat beras yang dimasak terpapar panas langsung pada dinding kuali/panci. Intip hubungannya dengan camilan dapat diartikan sebagai makanan ringan yang terbuat dari nasiyang dijemur, digoreng. Variasi rasa ada yang standart (asin), manis (ditambah gula merah) dan variasi lain. Dilihat dari cara pembuatan intip nasi dapat dibedakan menjadi dua jenis intip yaitu intip asli dan buatan,sebagai contoh dapat dilihat di gambar 1 dan 2 .

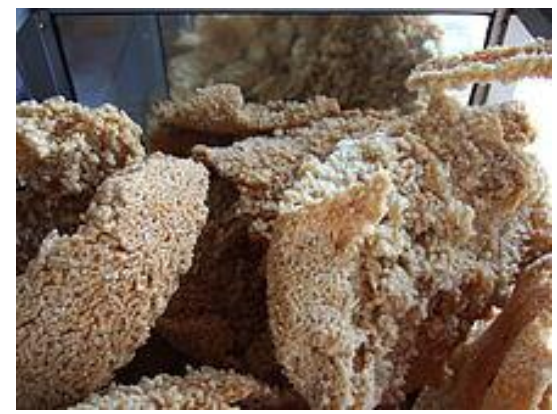

Gambar 1. Intip asli

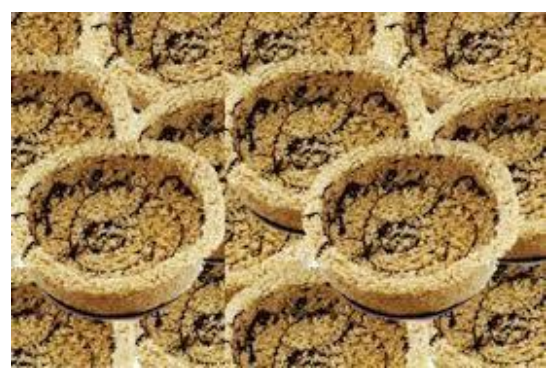

Gambar 2. Intip buatan 
Kandungan nutrisi intip Goreng per 100 gr adalah: Bagian Intip Goreng yang dapat dikonsumsi (Bdd / Food Edible $)=$ $100 \%$. Jumlah Kandungan Energi Intip Goreng $=474$ kkal. Jumlah Kandungan Protein Intip Goreng $=7,6$ gr. Jumlah Kandungan Lemak Intip Goreng $=21,6$ gr. Jumlah Kandungan Karbohidrat Intip Goreng $=62,3$ gr. Jumlah Kandungan Kalsium Intip Goreng $=323 \mathrm{mg}$. Jumlah Kandungan Fosfor Intip Goreng $=46 \mathrm{mg}$. Jumlah Kandungan Zat Besi Intip Goreng $=2,5$ mgJumlah Kandungan Vitamin $\mathrm{A}$ Intip Goreng $=0$ IU. Jumlah Kandungan Vitamin B1 Intip Goreng $=0,25 \mathrm{mg}$. Jumlah Kandungan Vitamin C Intip Goreng $=0 \mathrm{mg}$.[8].

Di beberapa daerah dapat ditemukan UKM UKM intip, misal di Kabupaten Sragen terletak di desa Jati dan desa Kedungdowo, Kecamatan Sumberlawang. Dua desa ini merupakan sentra industri pembuat intip goreng. Ada 15 orang (UKM) dan karyawan mampu terserap tiap satu UKM sebanyak empat orang. Di Kota Solo keberadaan UKM atau sering disebut juga dengan industri kecil menengah (IKM) tersebar di beberapa tempat diantaranya Jl. Ir. Juanda, Tanggul, Kampung Sewu. Di Klaten, salah satunya yang terkenal adalah intip pak "No"yang beralamat di Ds. Lumbung Kerep, Kec. Wonosari, Kab. Klaten. Tempat survei diambil di dua tempat yaitu di Klaten (intip Pak No) dan di Solo yaitu di Tanggul Kampungsewu. Rata rata kapasitas produksi mampu mencapai 75-100 bungkus intip buatan per harinya. Jumlah tenaga kerja yang terserap berkisar 4-6 (tergantung permintaan intip). Kebutuhan bahan baku berupa beras mampu menghabiskan 4-5 kilogram beras. Intip goreng memiliki ukuran yang bervariasi, yaitu besar dan kecil. Harga utuk intip goreng ukuran sedang $\mathrm{Rp} 2.000$, intip ukuran kecil Rp 1.200.

Permasalahan utama yang ditemukan saat tim TTG melakukan survey ke UKM di Solo dan Klaten adalah salah satunya permasalahan proses produksi (proses pengeringan). Saat musim penghujan, proses produksi UKM mengalami penurunan $70-80 \%$ dari proses produksi normal. Berhentinya proses produksi disebabkan jumlah panas matahari yang sangat rendah. Kondisi yang demikian UKM membutuhkan sarana pengering yang tingkat ketergantungan terhadap panas matahari sangat rendah atau $0 \%$. Solusi yang ditawarkan adalah memodifikasi sebuah alat pengering yang efisien. Efisien pada penggunaan panas dan pemakaian bahan bakar.

Syafriyudin, 2009, menjelaskan bahwa mekanisme pengeringan diterangkan melalui penjelasan tentang teori tekanan uap. Air yang diuapkan terdiri dari air bebas dan air terikat. Airbebas berada di permukaan dan yang pertama kali mengalami penguapan. Air yang ada dipermukaan intip akan habis.Hal ini terjadi proses perpindahan air dan uap air dari bagian dalam bahan secara difusi. Terjadinya perpindahan ini disebabkan oleh perbedaan konsentrasi atau tekanan uap pada bagian dalam dan bagian luar bahan.

Proses pengeringan dapat dibagi menjadi dua periode yaitu periode laju pengeringan tetap dan laju pengeringan menurun. Mekanisme proses laju pengeringan menurun meliputi dua proses yaitu pergerakan air dari dalam intip ke permukaan bahan dan dari permukaan ke udara. Laju pengeringan menurun terjadi setelah laju pengeringan tetap dimana kadar air bahan lebih kecil dari pada kadar air kritis [5]. 
Beberapa tipe alat pengering antara lain screen conveyor dryer, tower dryer, screw conveyor dryer dan tray dryer (rak). Sumber panas yang dipergunkan dalam proses pengeringan ini dapat dibedakan menjadi dua yaitu dengan mempergunkan panas matahari dan non matahari.

Yource M. Bintang (2013) Alat yang dikembangkan adalah untuk proses pengeringan ikan. Daya tampungnya mampu mencapai 15-16 kg dan suhu ruang mencapai $50^{\circ} \mathrm{C}$ pada saat suhu udara luar maksimal $38^{\circ} \mathrm{C}$. Sumber panas yang dipergunakan adalah sumber panas matahari.

Ismail Thamrin (2011), medesain alat pengering ubi tipe rak dengan mempergunakan panas matahari dengan bantuan fasilitator kolektor panas. Di dalam ruang oven pada rak terjadi perbedaan besaran laju pengeringan ubi kayu. Rak 1 sebesar 1,89 gram/menit, rak 5 sebesar 0,73 gram/menit (yang paling rendah).

Wijoyo (2010), mengembangkan alat pengering untuk pengeringan minjo dengan sumber panas dari kompor/LPG. Alat pengering ini tipe rak dan berjumlah 6 rak tiap rak mampu menampung $2.5 \mathrm{~kg}$ bahan. Suhu di dalam ruang pengering mampu mencapai $58^{\circ} \mathrm{C}-60^{\circ} \mathrm{C}$ dan proses pengeringan selama 1 jam menghabiskan minyak sebesar 1.5 liter. Pola pemanasan ruang adalah panas didapat langsung dari sumbernya.

Bachtera Indarto (2017). Membuat alat pengering untuk bahan benih padi mempergunakan panas buang $\mathrm{AC}$, dengan ukuran 50x50x60 cm tipe rak (4 rak). Pengering ini mampu menurunkan kadar air hingga $11 \%$ selama 11 jam.

Beberapa pengembangan alat di atas baik yang mempergunakan sumber panas matahari maupun sumber panas lain mempunyai kelemahan kelemahan. Sumber panas dari panas matahari akan mengalami masalah manakalah saat musim penghujan datang. Beberapa jenis alat pengering yang mempergunakan sumber panas alternatif terletak pada terjadinya pembuangan panas melalui cerobang akibat panas berlebih. Efisiensi panas dan pemakaian bahan sangat rendah.

Didasarkan pada kondisi tersebut maka tim TTG mendesain sebuah alat pengering yang tidak mempunyai tingkat ketergantungan tinggi terhadap panas matahari $(0 \%)$ dan juga memperbaiki gas buang yang mampu dijadikan suhu awal saat udara tekan dipanasi. Pengkondisian udara yang masuk ke heat exchangerdengan suhu awal menyebabkan pemanasan oleh heat exchangerakan lebih rendah suhunya dan jumlah pemakaian bahan bakar mampu lebih efisien.

Hasil desain alat tersebut adalah sebuah pengering dengan prinsip memutar udara panas. Udara dipanaskan oleh heat exchanger di tekan dan masuk ke ruang pengering. Udara akan dihisap blower untuk dilewatkan kembali ke heat exchanger, Alat ini didisain agar perbedaan suhu di rak bawah sampai atas sedikit perbedaanya. Heat ahchanger diletakkan dibawah ruang pengering dan dibuat by pass. Terdapatnya saluran langsung ke ruang pengering memberikan dampak pula pada kecepatan capaian suhu yang diinginkan. Ruang pengering didesain dengan cara pemberian penyekat. Sebelah kiri penyekat berbahan dasar kawat ram dan disebekah kanan penyekat berbagahn dasar plat stainless. Jadi pada jenis alat pengering ini tidak ada udara panas yang dibuang (sirkulasi tertutup). 


\section{METODE PELAKSANAAN PROGRAM}

Guna penyelasaian pelaksanaan program ini, maka tim TTG membuat alur pelaksanaan program.

Tabel 1. Alur penyelesaian program

\begin{tabular}{ll}
\hline No & \multicolumn{1}{c}{ Tahapan Pelaksanaan } \\
\hline 1 & Tahapan awal pelaksanan, yaitu: \\
& - Survey \\
& - Diskusidenganpihak UKM \\
& - Pembuatangambarkerja \\
& - Inventarisalat \\
& - Pembelianbahan/ alat \\
& - Final gambarkerja
\end{tabular}

2 Tahapan pembuatan alat, yaitu:

- Pembuatanrangka utama

- Pembuatan rak

- Pembuatan heat exchanger

- Pembuatan dudukan blower

- Setting blower

- Penutupan rangka rak samping

- Penutupan rangka utama

3 Tahapan uji kinerja komponen alat, yaitu:

- Heat exchanger

- Sirkulasi udara panas

- Suhu ruang

4 Tahapan uji kinerja alat Pengering, yaitu

- Kecepatan kerataan penyebaran panas di ruang pengering.

- Kemampuan capaianderajatpanas

- Kemampuan kecepatan pengeringan intip

5 Tahapan uji skala UKM (Uji coba pengeringan intip oleh UKM), yaitu:

- Kecepatan kerataan penyebaran panas di ruang pengering.

- Kemampuan capaianderajatpanas

- Kemampuan kecepatan pengeringan intip

6 Tahapan perbaikan pasca uji coba skala UKM, yaitu:

- Pengecekan dan perbaikan saluran\

- Pengecekan dan perbaikan heat exchanger

- Pengecekan dan perbaikan ruang pengering

- Pengecekan dan perbaikan blower dan salurannya 


\section{HASIL DAN PEMBAHASAN}

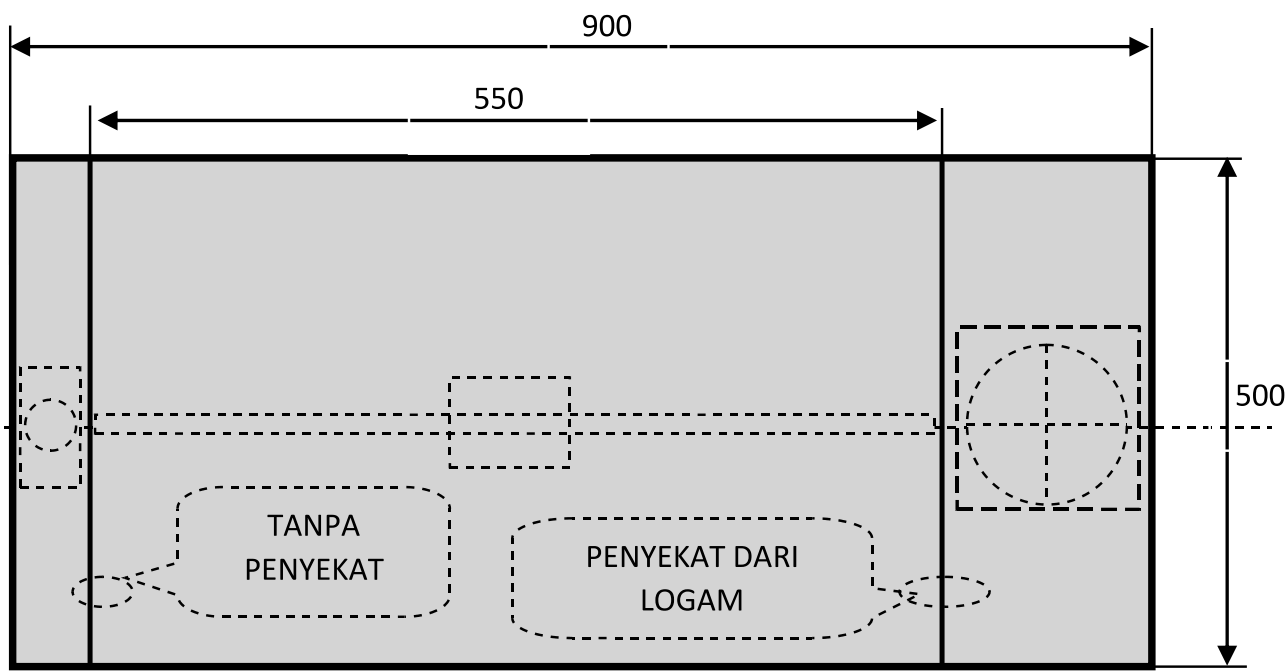

Gambar 2. Desain 2D alat pengering intip

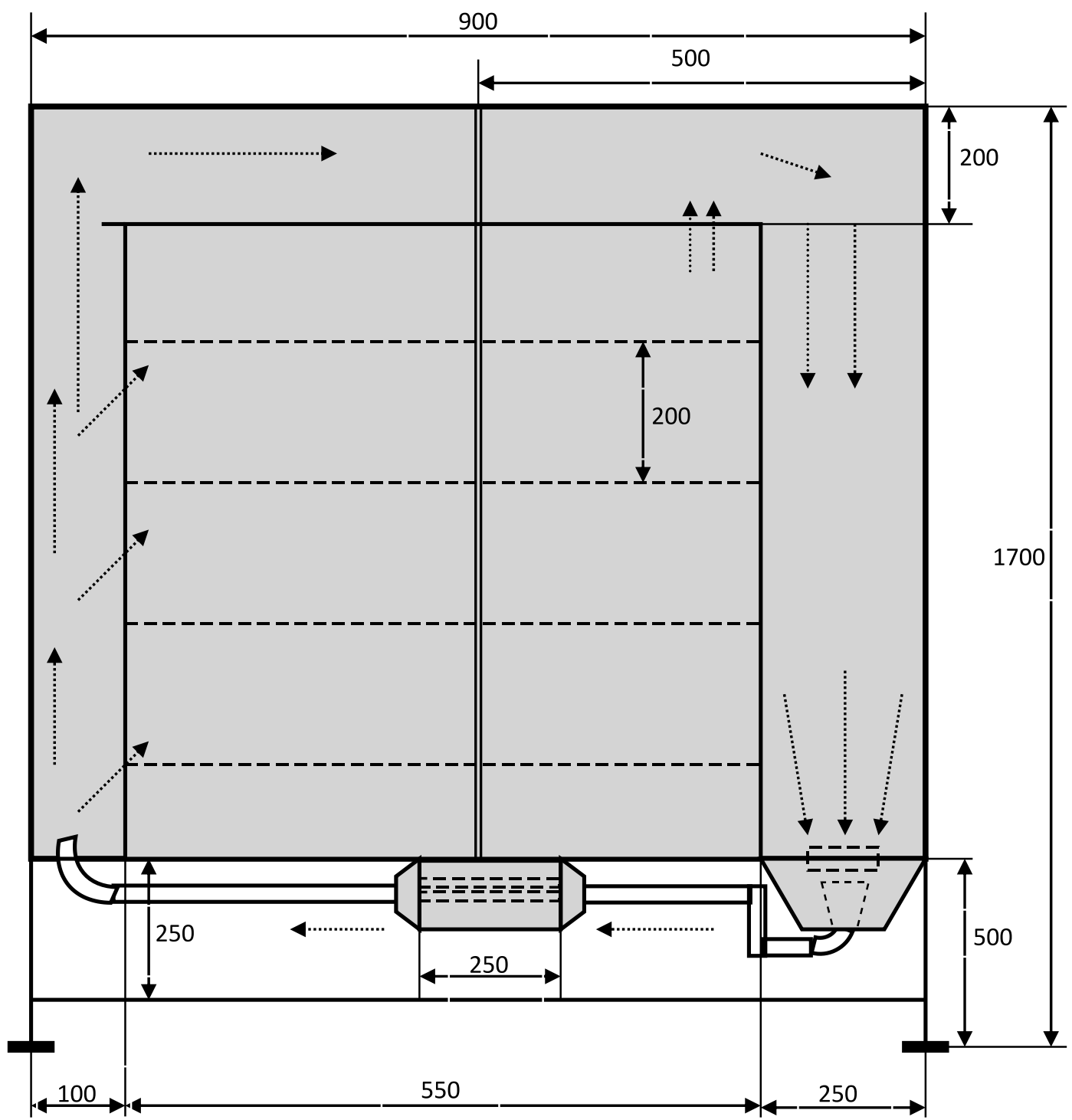


Gambar 3. Desain 2D alat pengering intip

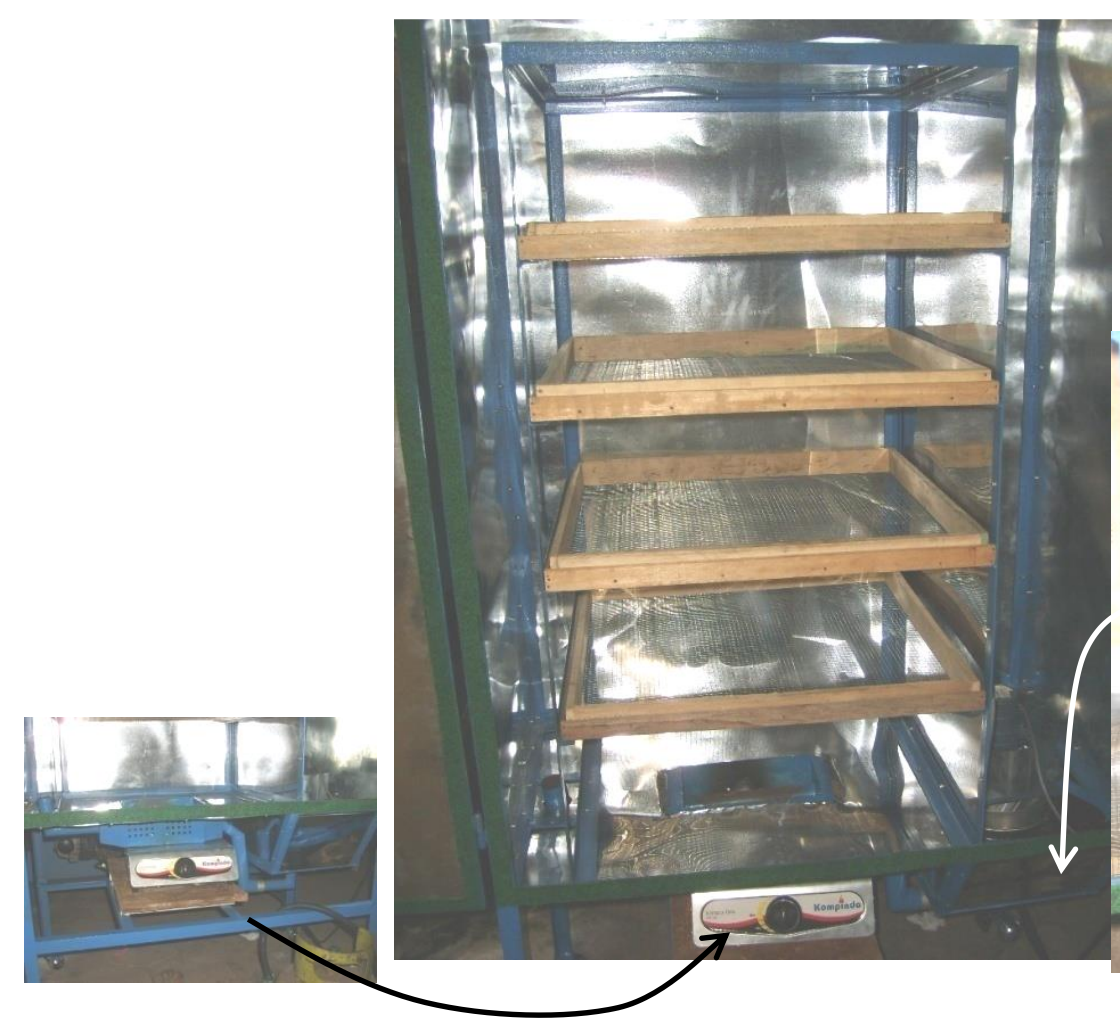

Dokumentasi alat pengering

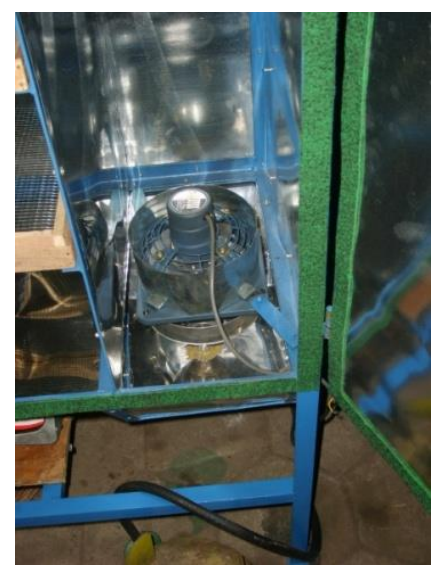

Gambar 5 Konstruksi blower

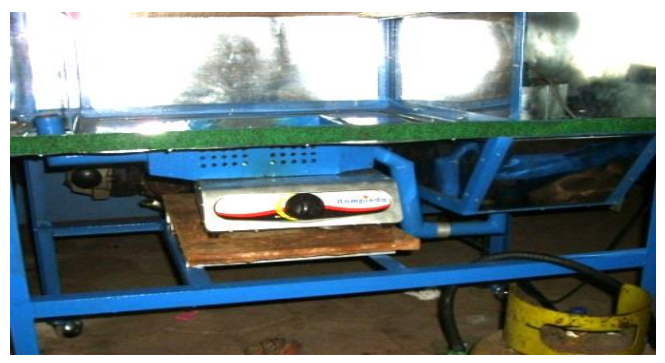

Gambar 6. Konstruksi saluran udara
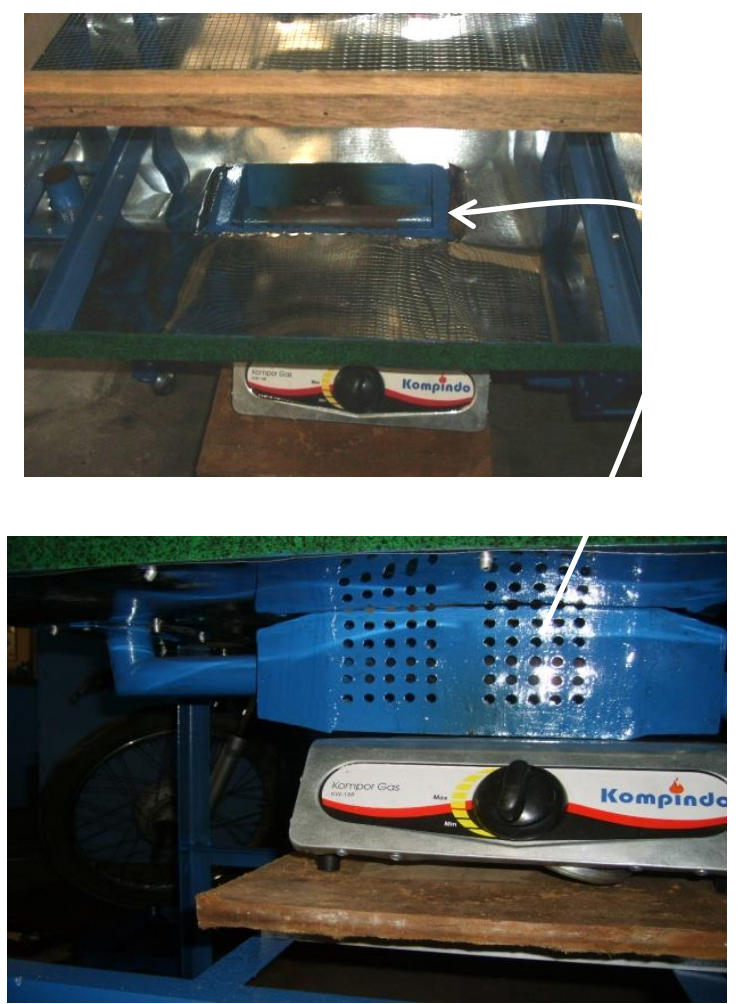

Gambar 7. Konstruksi sumber panas 
Gambaran perubahan suhu pada alat pengering pada tiap titik komponen dapat dilihat pada gambar 8 .

T 3

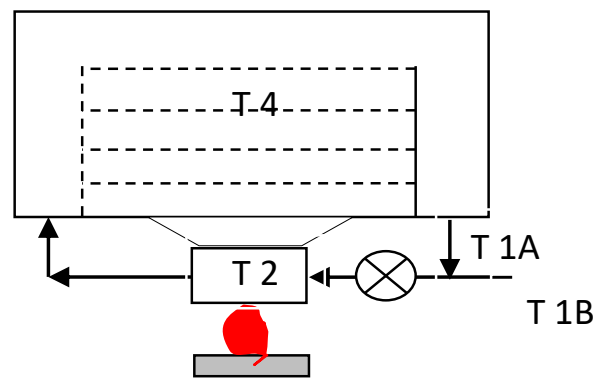

Gambar 8. Besaran besaran suhu pada tiap titik/posisi

Prosedur proses pengeringan adalah sebagai berikut:

1. Sumber panas dihidupkan. (gamabar 7)

2. Suhu pada $\mathrm{T} 2$ berkisar $35^{\circ} \mathrm{C}$, blower dihidupkan (gambar 5).

3. Suhu udara yang melewati heat exchanger(HE) dimana suhu $\mathrm{HE}$ mencapai $55^{\circ} \mathrm{C}$ akan meningkat menjadi $45^{\circ} \mathrm{C}$ dalam waktu 1 menit.

4. Suhu ruang pengering (T4) mencapai $100^{\circ} \mathrm{C}$ selama 7 menit.

5. Suhu awal yang dipergunakan dengan T1B sebesar $28^{\circ} \mathrm{C}$ maka akibat pemanasan $\mathrm{HE}$ akan meningkat menjadi $45^{\circ} \mathrm{C}$ (T3).

6. Suhu awal yang diambil dari suhu buang dari ruang pengering (T1A) setara dengan $50^{\circ} \mathrm{C}$, suhu $\mathrm{T} 3$ akan menjadi $60^{\circ} \mathrm{C}$.

7. Kecepatan capaian suhu di T5 akan meningkat seiring waktu pemanasan udara oleh heat exchanger.

8. Untuk mengurangi panas berlebihan saat menpergunakan T1B maka udara T5 dibuang.

9. Untuk mengurangi panas berlebihan saat mempergunakan T1A maka kompor LPG dimatikan atau di setting pada posisi api sangat kecil.

Beberapa nilai efisiensi pada komponen pengering adalah:

1. Efisiesni pemakaian heat exchanger pada input T1A dibandingkan input T1B.

Data yang diambil dengan variabel penggunaan waktu yang sama \pm 2 menit pada pemanasan $\mathrm{HE}$ didapat suhu T3, sebesar:

Input T1B sebesar $45^{\circ} \mathrm{C}$

Input $\mathrm{T} 1 \mathrm{~A}$ didapat $60^{\circ} \mathrm{C}$

Terjadi peningkatan sebesar 33\% dengan suhu awal masuk yang dipanaskan.

2. Efisiensi kalor

Didasarkan pada data capaian suhu ruang pengering sebesar $150^{\circ} \mathrm{C}$ selama 7 menit dan suhu input $28^{\circ} \mathrm{C}$ (T1B) dan $45^{\circ} \mathrm{C}$ (T1A). Kalor dapat dihitung efisiensinya didasarkan pada pendekatan Azas BLACK (Q in $=\mathrm{Q}$ out $)$ didapat $\pm 10 \%$ lebih rendah kalor yang diperlukan untuk memanaskan dengan T1A.

3. Efisiensi pemakaian LPG

Hasil dari pengambilan data saat proses pengeringan selama 5 jam pada $\mathrm{T} 4$ sebesar $32^{\circ} \mathrm{C}$ (suhu panas matahari) input udara pada T1A dan T1B, didapat:

$\mathrm{T} 1 \mathrm{~A} \rightarrow 1.75 \mathrm{~kg} \mathrm{LPG}$

$\mathrm{T} 1 \mathrm{~B} \rightarrow 3.25 \mathrm{~kg} \mathrm{LPG}$

Efisiesni sebesar $\pm 46 \%$

Capaian kecepatan pemanasan di ruang pengering (T4) saat uji kinerja alat adalah $120^{\circ} \mathrm{C}$ per50 menit pada kondisi 4 rakberisi intip @ sebanyak 1 kg (total 4 kg). Pada saat rak tidak ada intip, capaian suhu di $\mathrm{T} 4$ adalah sebesar $100^{\circ} \mathrm{C}$ selama 7 menit. Jadi 
setiap menit di T4 rak yang terisi intip, suhu capaiannya $2.4^{\circ} \mathrm{C} /$ menit dan tanpa intip $14.3^{\circ} \mathrm{C}$. Efisiensi pengeringan saat proses pengeringan intip adalah $17 \%$ tiap menitnya.

Alat pengering ini mempunyai ukuran 900 x 50 x $170 \mathrm{~mm}$. Jumlah rak sebanyak 4 rak dan jumlah rak bisa ditambah. Penambahan jumlah rak pengering dalam ruang oven akan berdampak pada capaian suhu di runag pengering lebih lambat

Pemakaian sumber panas mampu divariasikan, baik pemakaian yang berasal dari LPG (gambar 7), arang atau dari sumber lainnya dengan melakukan pengkondisian dibawah heat exchanger.

\section{SIMPULAN}

Hasil dari pelaksanaan program ini adalah

1. Saatmusimpenghujan UKM tetap mampu berproduksi seperti kondisi normal (musim panas) yaitu minimal sebanyak 75-100 bungkus intip per harinya. Setara dengan Rp. 150.000 Rp. 200.000 per hari.

2. Kecepatan capaian suhu ruang pengering mampu dikondisikan dengan pengaturan sumber panas.

\section{DAFTAR PUSTAKA}

Andrew Parr. Edisi ke dua." Hidrolika dan Pneumatika”. Penerbit Erlangga: Jakarta.

Bintang, Y.M., Pongah, J. dan Onibala, H. (2013). Konstruksi dan Kapasitas Alat Pengering Ikan Tenaga Surya Sistem Bongkar-Pasang. Jurnal Media Teknologi Hasil Perikanan. Volume 1, Nomor 2 Agustus 2013.

Indatto, B., Puspitasarim, S. dan Sunarno, H. (2017). Pemanfaatan Panas Buang Air Conditioner (AC) Pada Lemari Pengering Benih Padi. Jurnal Fisika dan Aplikasinya. Volume 13, Nomor 3 Oktober 2017.

Sularso. 1997. “Dasar Perencanaan Dan Pemilihan, Elemen Mesin”. Penerbit PT. Padnya Paramita: Jakarta.Thamrin, I. danKharisandi, A. (2011). Rancang Bangun Alat Pengering Ubi Kayu Tipe Rak Dengan Memanfaatkan Energi Surya. Prosiding Seminar Nasional AvoER ke-3, Palembang, 26-27 Oktober 2011

Syarifudin dan Purwanto, D.P. (2009). Oven Pengering Kerupuk Berbasis Mikrokontroler Atmega 8535 Menggunakan Pemanas Pada Industri Rumah Tangga. Jurnal Teknologi IST AKPRIND, vol. 2, 2009

Wijoyo, Nurhidayat, A. dan Sugiyanto, (2010). Rekayasa Alat Pengering Untuk Meningkatkan Produktifitas UKM Emping Mlinjo. Prosiding Seminar Sains dan Teknologi 2010 Fakultas Teknik Universitas Wahid Hasyim Semarang.

http://www.organisasi.org/1970/01/isi-kandungan-gizi-intip-goreng-komposisi-nutrisi-bahanmakanan.html) 